\title{
Analysis of Errors Committed by Students in Writing English Essays
}

\section{Lok Raj Sharma}

Associate Professor of English

Makawanpur Multiple Campus, Hetauda, Nepal

E-mail: lokraj043@gmail.com

DOI: https://doi.org/ 10.3126/irjmmc.v2i4.41551

Received: December 5, 2021; Revised \& Accepted: December 7, 2021; Published: December 24, 2021

(C) Copyright: Sharma (2021).

\section{ABSTRACT}

Error analysis in linguistics is a systematic process of collecting, identifying, describing, explaining and evaluating unaccepted linguistic forms committed by learners in their writings or speeches. This article attempts to assess the errors committed by 128 bachelor first year education students studying English as a foreign language at Makawanpur Multiple Campus, Hetauda, Nepal in the year 2021. Every student was assigned to write an essay on 'The Impact of Corona Pandemic on Students' in about 500 words as the written language sample in a free mode. 128 essays were selected as a sample through the simple random sampling method lottery from 190 essays. All the errors in their essays were identified, described, classified, explained and analyzed. The results revealed that most of the students committed errors in omission at the sentence level, and the causes of the errors were due to intralingual transfer, whereas the highest frequency of errors at the word level was preposition resulted due to mother tongue transfer and overgeneralization.

Key Words: English essay, error, errors analysis, interlingual, intralingual, writing

\section{INTRODUCTION}

Error analysis is a prominent task in the field of teaching and learning language. Fundamentally, teachers in Nepal assign their students to write essays to examine their linguistic competence and performance. Several class assignments as well as civil service examination papers retain essay writing; and the students or participants need to secure good marks to be promoted or to get the job.

English has been taught as a foreign language despite its charming and mounting popularity day by day in Nepal. According to Maharjan (2009), Nepali, the national language for the Nepalese, is used all over Nepal for official as well as everyday communicative functions (p. 71). Nepalese students are hardly exposed to English language at home. Even at colleges, they get some exposure only in the English subjects. As a result, they feel difficulty in writing and speaking in English.

Writing is an utterly complex skill. Learners are required to have sound knowledge of words, grammar, punctuation, syntax and pragmatism to write well. Ananda, Gani and Sahardin (2014) opine writing as the toughest of the vital skills for educating learners of English in an EFL context (p. 81). The written text must be grammatically accurate, logically planned, semantically intelligible and syntactically specific. Therefore learners must retain 
writing skills. Rozimela (2004) focuses on the necessity of proficiency of English writing skills in acquiring English language learning goals (p. 83). Similarly, Leki (2011) asserts that comprising sufficient writing skills assists our readers understand our ideas very easily (p. 5). It is vital for students to learn how to write compositions precisely and confidently, and it is essential to the teachers to give feedbacks to the students so that they can improve their writings in the days to come.

An essay is a well- structured piece of composition. It retains three parts: introduction, body and conclusion. Each introduction and conclusion has a paragraph, whereas the body may have one or more paragraphs depending on the nature of the subject. Essays can be good sources of data for the teachers to analyze errors of the learners, because they can be written on any topics in any length. It is a reliable and explicit genre of writing through which students can express their information, experiences, feelings, emotions and opinions with their language. Language is a unique treasure of mankind, and it can be learnt, improved and enhanced through persistent practice. Sweet (1992) defines language as a technique of expressing ideas in which speech sounds are combined into words, words are combined into sentences, and sentences are combined to provide answers to thoughts and ideas (p. 45). The expressed ideas and information remain ambiguous and unintelligible if they lack sound knowledge of language use in practice. They need to be aware of their errors to improve the writings.

The students, with diverse cognitive potentialities, family backgrounds, geographical distributions, mother tongues and their attitudes towards English reading and writing goals come to study at Makawanpur Multiple Campus, Hetauda, the largest and oldest one in the district of Makawanpur, may commit divergent errors in their writings. This research article aims at finding out the types of errors committed by those students and the sources of those errors so that the teachers can give them feed backs to improve their English.

\subsection{Objectives of the study}

The objectives of the study are:

a. To assess the types of error made by bachelor first year education students of Makawanpur Multiple Campus, Hetauda.

b. To find out the possible causes of those errors.

c. To make recommendations for future researchers, teachers, students, and curriculum planners.

\subsection{Literature Review}

Literature review includes basic concept of mistake and error, types of errors, sources of errors, error analysis and previous studies on error analysis.

\subsection{Mistake and Error}

A mistake is an unaccepted linguistic form noticed irregularly at the performance level of the language learner in his writing or speech, whereas an error is a marked deviation observed regularly at the competence level due to lack the knowledge of the language use in writing or speech. Norrish (1987) defines a mistake as an unpredictable deviation from the standard form (p. 8). Richards (1984) points out the causes of mistakes with the remarks that a mistake is made by a learner owing to fatigue, carelessness and the lack of attention (p. 95). 
Similarly, Richards and Schmidt (2002) define an error as the faulty use of language because of incomplete learning of language use (p. 184). Gass and Selinker (2001)assume the errors to act as red warning signals mirroring the learners' lack of knowledge of the target language. Mistakes can be corrected by the learners themselves, while errors can't be. The same opinion is mentioned by Ellis (1996) who claims that errors cannot be self-corrected by the learners (p. 17).Furthermore, Corder (1974) remarks that errors are produced because of incomplete learning and linguistic incompetency of the learners (p. 259) Therefore, errors should be taken seriously and the teachers need to take remedial steps to improve language competence that is revealed at the performance level of the earners.

\subsection{Types of Errors}

Errors can be classified in varied ways. Richards (1971) classifies errors into three major categories: interference errors, intralingual errors and developmental errors. Interference errors occur when the language learners use their mother tongue to produce a sentence in the target language. Intralingual errors reflect general features of the rule learning such as defective generalization, deficient application of rules and failure to learn conditions under which rules are utilized. On the other hand, developmental errors occur when learners endeavor to form hypothesis about the target language on the basis of limited experiences. Corder (1974) categorizes errors into three types as pre-systematic, systematic and postsystematic errors. A learner commits errors randomly, because he is not conscious of the rules or system of the language in pre-systematic error. He cannot correct the errors himself. A learner in systematic errors makes errors because of his incomplete knowledge of the language. His errors are regular and predictable and they cannot be corrected, whereas in post-systematic errors, a learner produces incorrect forms inconsistently because of the lack of attention or lapses of memories to apply the rules consistently, but he can correct the errors himself. Varieties of errors can also be underscored on the basis of surficial categorization as omission, addition, substitution, misformation and disordering errors. Dulay, Burt and Krashen (1982) consider an omission as a sort of error that is distinguished by the absence of an item that must appear in a well-formed utterance (p. 154). They view an addition as "a type of error which is characterized by the presence of an item which must not appear in wellformed utterance (p. 156), and misformation errors as defined by the usage of a morpheme or structure that is incorrect (p. 158). Substitution indicates the use of one word in the place of other word. Disordering is considered as the incorrect position of a morpheme or group of morphemes in a sentence pattern. Dulay et al (1982) support this concept through their expression these types of errors are typified by the inaccurate placement of morpheme or group of morphemes in an utterance (p. 162). Errors are described as phonological errors, graphological errors, grammatical errors, semantic errors, discourse errors and paralinguistic errors on the basis of deep level classification. Other types of errors are individual and group errors, productive and receptive errors, overt and covert errors, and local and global errors.

\subsection{Sources of Errors}

Brown (2002) points out two main sources of errors: interlingual transfer and intralingual transfer (p. 224). Interlingual transfer is a source of error which influences the foreign language learning negatively due to the mother tongue of the learner, whereas intralingual transfer is a source of error which tends to make the learner apply the incorrect 
generalization of the rules within the target language because of lack of correct learning of language use.

\subsection{Error Analysis (EA)}

Error analysis is a procedure that involves collecting, identifying, classifying and interpreting the unacceptable linguistic forms produced by a learner while learning a foreign or second language. Richards and Schmidt (2002) defines error analysis as the study and scrutiny of the errors committed by second language learners (p. 184). James (2001) takes EA is as the study and analysis of linguistic unawareness noticed in writing and speech (p. 62). Similarly, Özkayran and Yilmaz (2020) describe EA as kinds of language analysis done by focusing on the errors learners make (p. 50). It is a linguistic tool for analyzing language learning in order to improve language competence and performance in learners in a real life situation. Corder (1974) highlights the usefulness of error analysis in second language learning as it exposes the problem vicinities to teachers, syllabus designers and textbook writers in learning language (p. 125). It clearly indicates that EA is an essential task in language teaching learning activities. It must be regularly performed for improving language skills in students.

\subsection{Previous Studies on Error Analysis}

Darus and Subramaniam (2009) in their study found that most errors made by Malaysian students were grammatical problems along with singular/plural form, verb tenses, word choice, prepositions, subject-verb agreement and word order.

The research study carried out by Sarfraz (2011) showed that majority of Pakistani students committed grammatical errors due to intralingual procedure. Yahya, Ishak, Zainal, Faghat and Yahaya (2012) conducted a research on error analysis that revealed that most of the Malaysian students made errors in singular-plural form because of their mother tongue interference. A research study brought about by Ridha (2012) depicted that a lot of Iraqi students produced grammatical and mechanical errors owing to their mother tongue interference. Similarly, a research study conducted by Sawalmeh (2013) demonstrated that the most error committed by the Saudi Arabian students was verb-tense occurred by the first language transfer. . Klimova (2013) reported that Czech students had a problem with objectivity of abstracts, word order, articles, tenses, subject-verb agreement, rhetorical structures, punctuation and spelling, capital letters when they were writing in English. Ananda, Gani and Sahardin (2014) in their study found that the most frequent error was fragmented sentences $(74 \%)$.

Furthermore, Amiri and Puteh (2017) carried a research study which exposed that the most of Iranian students did errors in forming sentence structure and the reason behind it was their mother tongue interference. The research study of Onyinyechi (2017) on error analysis displayed the punctuation errors as the most serious errors made by Nigerian students as a result of their mother tongue interference.

Sermsook, Liamnimitr and Pochakorn (2017) examined written tasks in English produced by Thai university students, and found that punctuation was the major problem. The reviews of the previous studies on EA show that there was neither a same type of error committed by the students or a same cause of committing it. 


\section{METHODOLOGY}

The researcher adopted the following methodological elements to carry out the research.

\subsection{Research Design}

A cross-sectional research design was employed to carry out the research study.

\subsection{Population}

The population of the study consisted of 190 bachelor first year education students studying at Makawanpur Multiple Campus, Hetauda, Nepal in 2021.

\subsection{Sampling Design and Sample Size}

The researcher followed the simple random sampling technique as a sampling design and selected the 128 students' essays by maintaining 5\% margin of error at the significance level $95 \%$ by using the sample size determining software http://www.raosoft.com/samplesize.html. Creswell (2003) affirms that randomization from a population gives the ability to generalize a larger population (p. 156).

\subsection{Nature and Sources of Data}

The researcher used the nominal data whose primary source was the essays of the students. The nominal data were quantified to measure the gravity of errors by sing frequency and percentage as statistical tools. The secondary sources of data were books and journal articles.

\subsection{Stages of Error Analysis}

The analysis of errors in the essays was based on Corder's (1974) method which embraced the five proceedings: collection, identification, description, explanation and evaluation of errors.

\subsection{Collection of Data}

The data for the analysis of errors were elicited from the corpus of essays written by the students.

\subsection{Identification and Description of Errors}

The researcher identified five types of surficial errors at the syntactic level, and 3826 errors in the use of nouns, main verbs, adjectives, adverbs, auxiliary verbs, pronouns, articles, prepositions, conjunctions, verbs-tenses, sub-verb agreements, conditional sentences, possessive cases, spellings, capital / small letters, and punctuation marks.

Table 1: Surficial Classification and description of

\section{Errors}

\begin{tabular}{|l|l|l|l|}
\hline S.N. & Surficial Classification of Errors & Frequency & Percent of Errors \\
\hline 1. & Disordering / Misordering & 201 & 8.90 \\
\hline 2. & Substitution & 302 & 13.38 \\
\hline 3. & Misformation & 342 & 15.14 \\
\hline 4. & Addition & 640 & 28.34 \\
\hline 5. & Omission & 773 & 34.24 \\
\hline \multicolumn{2}{|c|}{ Total } & 2258 & 100 \\
\hline
\end{tabular}


This table shows that the highest percent of errors was omission (43.24\%), whereas the second highest percent of errors was addition (28.34\%). Similarly, the third and fourth highest percents of errors were misformation (15.14\%) and substitution (13.38). Moreover, the lowest percent of errors was disordering (8.90\%) despite the difference in sentence patterns in Nepali and English languages. The default sentence pattern in Nepali is Sub + Obj + Verb, and in English, it is Sub+ Verb+ Obj.

Table 2: Errors in the Use of Diverse Grammatical Aspects

\begin{tabular}{|l|l|l|l|}
\hline S.N. & Errors in the Use of & Frequency & Percent of Errors \\
\hline 1. & Punctuation Marks & 87 & 2.28 \\
\hline 2. & Possessive Cases & 95 & 2.49 \\
\hline 3. & Capital / Small Letters & 102 & 2.67 \\
\hline 4. & Pronouns & 128 & 3.34 \\
\hline 5. & Conjunctions & 160 & 4.19 \\
\hline 6. & Main Verbs & 164 & 4.28 \\
\hline 7. & Adjectives & 196 & 5.12 \\
\hline 8. & Conditional Sentences & 203 & 5.30 \\
\hline 9. & Adverbs & 204 & 5.33 \\
\hline 10. & Verbs-Tenses & 240 & 6.28 \\
\hline 11. & Nouns & 246 & 6.43 \\
\hline 12. & Aux. Verbs & 284 & 7.42 \\
\hline 13. & Sub-Verb Agreements & 305 & 7.98 \\
\hline 14. & Spellings & 385 & 10.06 \\
\hline 16. & Articles & 459 & 11.99 \\
\hline 16. & Prepositions & 568 & 14.84 \\
\hline & Total Errors & 3826 & 100 \\
\hline
\end{tabular}

This table displays that the highest percent of errors was in the use of prepositions $(14.84 \%)$, whereas the lowest percent of errors was in the use punctuation marks $(2.28 \%)$. It was observed that the highest frequency of errors in the use of preposition was owing to the overgeneralization and mother tongue interference.

\section{EXPLANATION OF ERRORS}

The researcher considered only two causes of errors intralingual transfer and interlingual transfer; however the intralingual transfer involved the cases of overgeneralization, hypercorrection, erroneous input, faulty analogy and overlooking cooccurrence restriction. Similarly, interlingual transfer includes the mother tongue interference caused by different features between the Nepali language and the English language, and the absence of the use of a linguistic form available in another language. 
Table 3: Intralingual Transfer and Interlingual Transfer in Writing

\begin{tabular}{|c|c|c|c|c|c|c|}
\hline \multirow[t]{2}{*}{ S.N. } & \multirow{2}{*}{$\begin{array}{l}\text { Surficial Classification of } \\
\text { Errors }\end{array}$} & \multirow[t]{2}{*}{ Frequency } & \multicolumn{4}{|c|}{ Causes of Errors } \\
\hline & & & \multicolumn{2}{|c|}{$\begin{array}{l}\text { Intralingual } \\
\text { Transfer }\end{array}$} & \multicolumn{2}{|c|}{$\begin{array}{l}\text { Interlingual } \\
\text { Transfer }\end{array}$} \\
\hline 1. & Disordering / Misordering & 201 & 187 & $(93.03 \%)$ & 14 & $(6.97 \%)$ \\
\hline 2. & Substitution & 302 & 298 & $(98.67 \%)$ & 4 & $(1.33 \%)$ \\
\hline 3. & Misformation & 342 & 341 & $(99.70 \%)$ & 1 & $(0.30 \%)$ \\
\hline 4. & Addition & 640 & 637 & $(99.53 \%)$ & 3 & $(0.47 \%)$ \\
\hline 5. & Omission & 773 & 749 & $(96.89 \%)$ & 24 & $(1.11 \%)$ \\
\hline & Total & 2258 & 2212 & $(97.96 \%)$ & 46 & $(2.04 \%)$ \\
\hline
\end{tabular}

This table reveals that the major cause of errors committed by the students in their essay writing was intralingual transfer. They did not have sufficient knowledge of English language. Most of the students over- generalized the rules and committed errors.

\subsection{Evaluation of Errors}

Omission was observed as having the highest gravity of errors, and the second highest gravity was found in the use of addition in the surface classification. They avoided the essential linguistic forms and added unnecessary forms in their writing such as, "the Coronavirus has been spreading 'in world', 'the students have been spending their time at the homes', and so on. The use of preposition was seen as the most serious problem for the students in their writings such as 'the students are concerned with the Coronavirus', 'we have been staying at home from almost two years' and so on. Though articles sound to be easy, the students were found to commit errors in several places in their writing such as 'we like to go to the campus to study', ' she is a honest student', and so on. The biggest cause of committing errors was the intralingual transfer. Most of the students did not have the sound knowledge of English. They were habituated in making overgeneralization. English is a crazy language, because overgeneralization in word formation, use of auxiliary verbs, adverbs and pronunciation can't work in several points.

\section{CONCLUSION}

EA is a systematic process of investigating the errors committed by learners. This research study shows that the most committed error was omission at the syntactic level, and preposition at the lexical level. Furthermore, the biggest cause of errors was the intralingual transfer. This article is significant to both the teachers and the students, because it explores the errors and causes of committing them. The teachers can give food backs to his students and teach them well by focusing on their errors for improving language skills in the students.

\section{RECOMMENDATIONS}

The following practicable recommendations are made on the basis of research findings:

i. It is recommended the future researchers to undertake further research from the primary level to the higher secondary level to examine students' preliminary problems in learning English.

ii. Teachers should encourage their students to be engaged in writing to use language in the different contexts for diverse purposes. 
iii. Teachers should provide regular positive feedback and motivation after correcting the students' writings.

iv. Students should practise English grammar rules and identify the specific rules of the language and use them in different situations accordingly. They should also develop vocabulary power.

v. Students are recommended to write different essays to achieve their language proficiency again and again.

vi. Curriculum planners should consider their learners' needs and include relevant aspects of English writing while developing teaching materials.

\section{REFERENCES}

Amiri, F., \& Puteh, M. (2017). Error analysis in academic writing: A case of international postgraduate students in Malaysia. Advances in Language and Literary Stidies, 8(4), 141-145.

Ananda, R., Gani, S., \& Sahardin, R. (2014). A study of error analysis from students' sentences in writing. Studies in English Language and Education, 1(2), 81-95.

Brown, H. D. (2002). Principles of language learning and teaching (4 th ed.) . NY 10606: Addison Wesley Longman.

Corder, S. P. (1974). Error Analysis. In J. P. B. Allen and S. P. Corder (eds.) Techniques in Applied Linguistics . (J. P. Linguistics, Ed.). Language and Language Learning, 122154.

Creswell, J. W. (2003). Research design: Qualitative, quantitative, and mixed methods approaches (2nd ed). Thousand Oaks, C. A.: Sage.

Darus, S., \& Subramanian, K. (2009). Error analysis of the written English essay of secondary school students in Malasia: A Case study. European Journal of Social Sci $\neg$ ences, 8(3), 483-495.

Dulay, H., Burt, M., \& Krashen, S. (1982). Language Two. New York: Oxford University Press. .

Ellis, R. (1996). The study of second language acquisition. Oxford: Oxford University Press.

Gass, S., \& Selinker, L. (2001). Second Language Acquisi $\neg$ tion: An Introductory Course. Mahwah, NJ: LEA.

James, C. (2001). Errors in language learning and use: Exploring error analysis. Beijing : Foreign Language Teaching and Research Press. .

Klimova, B. (2013). Common mistakes in writing abstracts in English. Procedia - Social and Behavioral Sciences, 93, 512-516.

Leki, I. (2011). Academic writing: Exploring processes and strategies. New York: Cambridge University Press.

Maharjan, L. (2009). earners' Errors and their Evaluation. LJournal of NELTA, 14(1-2), 7181.

Norrish, J. (1987). Language learning and their errors. London: Macmillan Publisher Ltd. . Onyinyechi, O. G. (2017). Error analysis of the written English essays of junior secondary school two tudents in Owerri North. International Journal of Education and Evaluation, 3(5), 64-74. 
Özkayran, A., \& Y1lmaz, E. (2020). Analysis of higher education students' errors in English writing tasks. Advances in Language and Literary Studies, 2(2), 48-58.

Richards, J. (1971). Error analysis and second language strategies. Language Sciences, 17, $12-22$.

Richards, J. C. (1984). A non-contrastive approach to error analysis. English Language Teaching, 25, 204-219.

Richards, J. C., \& Schmidt, R. (2002). Dictionary of Language Teaching \& Applied Linguistics . London: Longman.

Ridha, N. (2012). The effect of EFL learners"e mother tongue on their writings in English: an error analysis study. Journal of the College of Arts University of Basrah, 60, 22-45.

Rozimela, Y. (2004). The value of English writing skills in Indonesia. In B. Y. Cahyono \& U. Widiati (Eds.), The tapestry of English language teaching and learning in Indonesia (pp. 83-98). Malang: State University of Malang Press.

Sarfraz, S. (2011). Error analysis of the written English essays of Pakistani undergraduate students: A case study. Asian Transactions on Basic \& Applied Sciences, 1(3), 29-51.

Sawalmeh, M. (2013). Error analysis of written English esssays: The case of students of the reparatory year program in Saudi Arabia. English for Specific Purposes World, 14(40), $1-17$.

Sermsook, K., Liamnimitr, J., \& Pochakorn, R. (2017). An analysis of errors in written English sentences: A case study of Thai EFL students. English Language Teaching, 10(3), 101-110.

Sweet, S. (1992). Language and the study of language (4th ed.). New York: Merrill Publishing Company.

Yahya, A., Ishak, H., Zainal, Z., Faghat, L., \& Yahaya, N. (2012). Error analysis of L2 learners' writings, a case study. International Conference on Language, Medias and Culture, 33, 114-118. 